\title{
The effect of human activities on moisture content of soils and underlying permafrost from the McMurdo Sound region, Antarctica
}

\author{
I.B. CAMPBELL', G.G.C. CLARIDGE' and M.R. BALKS ${ }^{2}$ \\ ${ }^{1}$ Land and Soil Consultancy Services, 23 View Mount, Stoke, Nelson, New Zealand \\ ${ }^{2}$ Department of Earth Sciences, University of Waikato, Private Bag 3105, Hamilton, New Zealand
}

\begin{abstract}
Soils and the underlying permafrost from undisturbed sites and sites that had been disturbed by construction activities at Marble Point and Pram Point in the McMurdo Sound region were sampled from excavated pits and drill cores. Gravimetric moisture (ice) contents and particle size distribution were determined. Volumetric moisture contents were calculated from these results. At undisturbed sites soil moisture contents within the active layer (to c. $60 \mathrm{~cm}$ depth) were low and ranged from $0.5 \%$ by weight at the soil surface to $10 \%$ above the permafrost. The permafrost was generally completely saturated with ice, but sometimes contained considerable excess ice, with ice contents rising as high as $80 \%$ by volume. At disturbed sites, soil moisture contents within the active layer were similar to those of the undisturbed sites (generally $<10 \%$ by weight) but within the permafrost, moisture contents were lower and less variable than in the undisturbed sites, rarely exceeding $20 \%$ by weight. The release of considerable quantities of water from the permafrost as a result of land disturbance during construction activities caused stream flows, soil shrinkage, land slumping and salinisation, resulting in significant permanent environmental damage. At Marble Point there has been no significant re-establishment of icy permafrost in the disturbed soils in the 30 years since land disturbance occurred.
\end{abstract}

Received 1 October 1992, accepted 26 April 1994

Key words: Antarctica, environmental damage, McMurdo Sound, moisture content, permafrost, soils.

\section{Introduction}

There is increasing concern about the impact of human activity on the environment of Antarctica and a realisation of the need for base-line data. Amongst greatest impacts on Antarctic terrestrial ecosystems are likely to be chemical contamination (accumulations in soils of heavy metals, hydrocarbons, etc.) or physical disturbance to the soils and underlying permafrost. Up to the present time little attention has been paid to the latter.

Continental Antarctic soils are in general almost completely devoid of organic matter and are coarse and stony (Campbell \& Claridge 1987). They are usually extremely dry, especially in the upper part of the profile. The freezing isotherm generally penetrates $20-50 \mathrm{~cm}$ into the soil during the warmest part of the summer, and below this depth they are permanently frozen. At or below this depth, the soils contain sufficient ice to be cemented, and the ice-cemented material is commonly referred to as permafrost. The difficulty of penetrating this hard material, and the absence of sections, have ensured that neither the properties of Antarctic permafrost nor the effects of disturbance on it have been studied to any extent.

Although there have been extensive studies of continental Antarctic soils, little attention has been paid to their moisture properties, either within the dry surface layer subject to diurnal and annual temperature fluctuations, any possible layer subjected to thawing and freezing of ice (active zone) or the underlying permanently frozen soil (permafrost). Specific information about the variability of Antarctic permafrost, its moisture characteristics, how it changes with time, its relationship to climatic parameters, or to what extent it may be modified by human activity is lacking.

In recent years there has been a considerable expansion of scientific activities and their supporting logistics in Antarctica, especially within the McMurdo Sound region. This has resulted in extensive landscape disturbance in areas subject to high population densities and activity levels. Around station areas on Ross Island, and at Marble Point where an airstrip wasconstructed in 1958/59, significant and extensive modifications to land surfaces have occurred. These include scraping of the loose surface material, diversion of water flows, scattering of debris, and the enhanced melting of snow and ice field after contamination with dust. The disturbances have been accompanied by changes in the permafrost including lowering of the permafrost table and release of water, release of salts from within the permafrost, and slumping and shrinkage of the ground surface.

The purpose of this paper is to characterize the properties of Antarctic permafrost in a continental coastal region and to evaluate the effects of disturbance on it.

\section{Environmental setting}

The Marble Point area, on the western side of McMurdo Sound, consists of about $20 \mathrm{~km}^{2}$ of ice-free undulating land up to $122 \mathrm{~m}$ above sea level. Formed from marble, schist and granodiorite, it is largely covered by a thin veneer of till deposited by retreat of the Wilson Piedmont Glacier, which borders the area on the west. 
Pram Point, at the southern tip of Ross Island, on the eastern side of McMurdo Sound, is an area of less than $1 \mathrm{~km}^{2}$ of ice-free sloping land formed from scoriaceous basaltic lava. No till deposits are recognized at Pram Point but the surface has been reworked by patterned ground movement and the formation of nivation cirques.

The surface deposits and soils are unweathered (weathering stage 1 of Campbell \& Claridge 1975) but some patches of older, well oxidized drift materials underlie the surface till in places at Marble Point.

Mean annual temperature of the two areas is $-18^{\circ} \mathrm{C}$, although summer temperatures are much warmer, within the range of $-7^{\circ}$ to $+10^{\circ} \mathrm{C}$ from early December to early February. Pram Point may be slightly colder than Marble Point. Precipitation is probably less than $200 \mathrm{~mm}$ water equivalent annually, but moisture available to the soil may be very much less owing to ablation of snow and evaporation of moisture. Soil temperatures are appreciably higher than air temperatures with the freezing isotherm penetrating to about $60 \mathrm{~cm}$ at Marble Point and $35 \mathrm{~cm}$ at Pram Point.

The soils studied at Marble Point were from an area where construction activities took place in 1958/59 during an investigation into the feasibility of building a major land based airfield. Apart from the maintenance of a small facility for refuelling helicopters and some clean-up activities, the land surfaces at Marble Point have remained essentially undisturbed since 1959. At Pram Point, there has been extensive and continuing disturbance in the 30 years since Scott Base was constructed and site history for disturbed areas is difficult to ascertain. However, some sites with uncomplicated disturbance histories can be located.

In this discussion, we use the term "permafrost" as usually defined,i.e. for soil that is perennially frozen, and "active layer" for the soil above the permafrost that is subject to annual or diurnal cycles of freezing and thawing. It is not always possible to separate the two clearly in the field as the time of inspection does not always coincide with that of maximum thaw. Soil in the active layer with as little as $5 \%$ water content may be frozen hard, ice-cemented and impossible to excavate prior to maximum thaw. On the other hand some dry soils may remain loose even when below freezing point, so that the depth to ice-cement may be greater than the depth to the permanently frozen layer. The term "ice-cement" has been used previously (Campbell \& Claridge 1987) to describe the hard frozen material encountered at the base of a soil profile whether above or below the maximum depth of penetration of the freezing isotherm.

\section{Methods}

\section{Sites}

Marble Point sites were selected on compacted fill on an old runway, on adjacent surfaces from which the surface unconsolidated material had been removed (cut surfaces) and from an embankment formed from material that had not been
Table I. Sampling site descriptions

Site No. Description

Marble Point

566 Undisturbed site, $75 \mathrm{~m}$ west of runway and $100 \mathrm{~m} \mathrm{NW}$ of helicopter facility buildings.

567 Undisturbed site, $10 \mathrm{~m} \mathrm{E}$ of northwestern end of runway.

568 Disturbed (fill) site, eastern edge of runway, $200 \mathrm{~m}$ north of helicopter refuelling site, on compacted fill.

583 Disturbed (fill) site, section through ridge formed by earthworks associated with flood protection of old construction camp site, on edge of lake adjacent to old camp, $1000 \mathrm{~m}$ south of present helicopter facility buildings.

569 Disturbed (scraped) site, scraped track, with about $60 \mathrm{~cm}$ of material removed, $20 \mathrm{~m}$ east of site 568 .

570 Disturbed (scraped) site, eastern side of runway, $75 \mathrm{~m}$ south of site 568.

571 Disturbed (scraped) site, bulldozed channel, $200 \mathrm{~m}$ NW of helicopter facility buildings and $20 \mathrm{~m}$ west of runway.

Pram Point

587 Undisturbed site, on a small knoll $400 \mathrm{~m}$ north of Scott Base.

588 Undisturbed site, in a dry nivation hollow, which accumulates snow periodically, $20 \mathrm{~m}$ northwest of site 587 .

589 Undisturbed site, in a nivation cirque $200 \mathrm{~m}$ north of McMurdo-Scott Base road, below $80 \mathrm{~cm}$ of snow.

597 Disturbed (fill) site, northern edge of McMurdo-Scott Base road, directly above Scott base, in compacted fill of track for pipeline construction. Construction work carried out 6 weeks prior to sampling.

598 Disturbed (fill) site, on compacted fill of pipeline track, $75 \mathrm{~m}$ west of site 597, but otherwise similar.

594 Undisturbed site, in a nivation cirque $200 \mathrm{~m}$ north of the McMurdo-Scott Base road, $200 \mathrm{~m}$ west of site $589.50 \mathrm{~m}$ from edge of snowbank

595 As for site 594, but $20 \mathrm{~m}$ from snowbank.

596 As for site 594, but at edge of snowbank.

589 As for site 594 , but under $50 \mathrm{~cm}$ of snow.

Sample numbers relate to the New Zealand Antarctic Soils Database.

compacted. Sites which had not been disturbed by construction activity during the feasibility investigation were also sampled for comparison.

Pram Point sites were selected on fill materials forming a recently constructed (1989) pipeline track, on land surfaces recently exposed by man-induced ablation (through dust accumulation) of a permanent snowfield (uncovered samples) and on a range of undisturbed sites. Details of the sampling sites are given in Table $\mathrm{I}$.

\section{Sampling and analyses}

At each site, the soils were examined by first digging a pit to the surface of the permafrost or frozen ground. The unfrozen soil profile was described from the side of the pit and c. $1 \mathrm{~kg}$ of sample 
was collected in a plastic bag. The low cohesion and coarse particle size of the soils and the difficult working conditions made it impossible to sample on a volume weight basis. The samples were double bagged, sealed and weighed. The frozen soil was sampled and examined by drilling into the permafrost with a motor-driven diamond-tipped barrel corer to depths of almost $2 \mathrm{~m}$ from the soil surface. The frozen core, drilled in $10-15 \mathrm{~cm}$ increments, was allowed to freeze in the core barrel so that it could be withdrawn from the hole. It was extracted by warming over a stove, then bagged and weighed. All samples were later reweighed at Scott Base and then oven dried and weighed to calculate the gravimetric water content.

The moisture contents of the samples were converted to a volumetric basis in twoways, depending on whether the soil was completely saturated with ice or not. The bulk density was estimated by packing a container with soil to a density approximately that of the natural material, and weighing the soil. This procedure provides a reasonably accurate measure as it is consistently found that the volume of soil removed from a soil profile pit matches with that required for its replacement. Because of the nature of the material and the environment it would be difficult to measure bulk densities on undisturbed material. At Marble Point the bulk density was found by this method to be $1.74 \mathrm{Tm}^{-3}$.

For unsaturated soils, where ice or water occupies some of the pore space, volumetric water content is calculated from the relation:

$$
\mathrm{W}_{\mathrm{v}}=1.74 \mathrm{~W}_{\mathrm{g}}
$$

where $\mathrm{W}_{\mathrm{v}}$ is volumetric water content (\%), $\mathrm{W}_{\mathrm{g}}$ is gravimetric water content, and 1.74 is measured bulk density.

For saturated soils, where ice occupies all the pore space and separates particles, and assuming a particle density of 2.8 the relationship is:

$$
\mathrm{W}_{\mathrm{v}}=100 \mathrm{~W}_{\mathrm{g}} /\left(\mathrm{W}_{\mathrm{g}}+35.7\right)
$$

The volumetric moisture content of a fully saturated sample was calculated to be approximately $38 \%$; thus any material with $\mathrm{W}_{v}$ greater than this value contained excess ice. The amount of excess ice in a square metre of each horizon was calculated, and combined to give the total excess ice content in the ice-cement.

The samples were sieved to determine the $2 \mathrm{~mm}$ fraction. To determine the water soluble salts the fine earth fraction was extracted with water (Metson 1956). The salt free soil was then treated to remove iron oxides (Mehra \& Jackson 1960) and separated into size fractions by sieving and sedimentation. The mineralogy of the clay and silt fractions was determined by $\mathrm{x}$ ray diffraction, differential thermal analysis, infrared absorption and electron microscopy, where appropriate.

\section{Results}

\section{Particle size differences}

Particle size distribution is related to pore space and waterholding capacity. Soils are generally bouldery, but the relevant figures are the proportion of fine earth $(<2 \mathrm{~mm})$ and the nature

Table II. Particle size distribution, extractable iron oxide content and total soluble salt concentrations (\%) of the >2mm fractions of soil 566 (Marble Point) and

\begin{tabular}{|c|c|c|c|c|c|c|c|c|c|c|}
\hline sample no. & $\begin{array}{l}\text { depth } \\
\mathrm{cm}\end{array}$ & $\begin{array}{c}2-0.5 \mathrm{~mm} \\
\%\end{array}$ & $\begin{array}{c}0.5-0.25 \mathrm{~mm} \\
\% \\
\end{array}$ & $\begin{array}{c}0.25-0.1 \mathrm{~mm} \\
\% \\
\end{array}$ & $\begin{array}{c}0.1-0.05 \mathrm{~mm} \\
\%\end{array}$ & $\begin{array}{c}0.05-0.02 \mathrm{~mm} \\
\% \\
\end{array}$ & $\begin{array}{c}0.02-0.002 \mathrm{~mm} \\
\% \\
\end{array}$ & $\begin{array}{c}<0.002 \mathrm{~mm} \\
\%\end{array}$ & $\begin{array}{c}\text { iron oxide } \\
\% \\
\end{array}$ & $\begin{array}{c}\text { total salts } \\
\% \\
\end{array}$ \\
\hline \multicolumn{11}{|c|}{ Marble Point, undisturbed site } \\
\hline $566 \mathrm{~h}$ & $4-0$ & 20.2 & 18.0 & 30.7 & 20.2 & 6.3 & 3.2 & 1.2 & 0.2 & 1.6 \\
\hline $566 \mathrm{i}$ & $0-27$ & 20.0 & 17.3 & 23.3 & 18.3 & 13.3 & 6.4 & 1.0 & 0.4 & 0.1 \\
\hline $566 \mathrm{j}$ & $27-48$ & 26.6 & 16.5 & 20.6 & 14.1 & 9.7 & 8.1 & 4.0 & 0.4 & 0.1 \\
\hline $566 \mathrm{k}$ & $48-65$ & 25.6 & 17.7 & 18.3 & 10.7 & 10.7 & 12.0 & 4.7 & 0.4 & 0.1 \\
\hline \multicolumn{11}{|c|}{ (ice-cement surface) } \\
\hline $566 a$ & $65-80$ & 24.4 & 20.1 & 22.7 & 12.2 & 9.0 & 7.4 & 3.0 & 0.3 & 0.05 \\
\hline $566 \mathrm{~b}$ & $80-95$ & 19.1 & 18.2 & 25.5 & 14.3 & 11.4 & 8.3 & 2.7 & 0.4 & 0.1 \\
\hline $566 c$ & $95-110$ & 17.9 & 17.8 & 22.5 & 14.6 & 13.0 & 10.4 & 3.2 & 0.5 & 0.2 \\
\hline $566 \mathrm{~d}$ & $110-118$ & 17.5 & 15.6 & 19.3 & 11.6 & 12.7 & 15.8 & 7.0 & 0.5 & 0.5 \\
\hline $566 \mathrm{e}$ & $128-148$ & 17.8 & 15.5 & 20.2 & 11.9 & 12.3 & 14.8 & 7.0 & 0.4 & 0.5 \\
\hline $566 f$ & $148-162$ & 21.2 & 14.7 & 16.8 & 12.9 & 11.7 & 14.2 & 8.1 & 0.4 & 0.5 \\
\hline $566 \mathrm{~g}$ & $162-175$ & 11.2 & 18.6 & 23.4 & 14.3 & 11.7 & 13.3 & 7.0 & 0.5 & 0.5 \\
\hline \multicolumn{11}{|c|}{ Pram Point, undisturbed site } \\
\hline $587 \mathrm{a}$ & $0-5$ & 51.7 & 16.6 & 16.6 & 5.4 & 2.9 & 4.5 & 2.2 & 0.2 & 0.1 \\
\hline $587 \mathrm{~b}$ & $5-10$ & 52.1 & 20.7 & 14.8 & 3.3 & 1.7 & 3.6 & 3.5 & 0.2 & 0.03 \\
\hline $587 \mathrm{c}$ & $10-15$ & 55.9 & 17.8 & 13.3 & 3.2 & 1.6 & 3.3 & 4.7 & 0.2 & 0.03 \\
\hline $587 \mathrm{~d}$ & $15-20$ & 61.1 & 17.5 & 11.6 & 2.9 & 1.1 & 2.3 & 3.2 & 0.2 & 0.01 \\
\hline $587 \mathrm{e}$ & $20-28$ & 62.3 & 20.0 & 9.8 & 2.3 & 0.8 & 2.0 & 2.5 & 0.2 & 0.01 \\
\hline \multicolumn{11}{|c|}{ (ice-cement surface) } \\
\hline $587 f$ & $28-34$ & 62.0 & 19.9 & 10.2 & 2.3 & 0.8 & 2.0 & 2.5 & 0.2 & 0.2 \\
\hline $587 \mathrm{~g}$ & $34-45$ & 23.0 & 19.1 & 20.7 & 10.6 & 12.0 & 10.2 & 3.2 & 1.3 & 0.1 \\
\hline $587 \mathrm{~h}$ & $45-57$ & 24.1 & 18.6 & 19.2 & 10.3 & 13.0 & 10.7 & 3.1 & 1.1 & 0.1 \\
\hline $587 \mathrm{i}$ & $57-63$ & 4.7 & 14.9 & 21.0 & 14.8 & 22.6 & 15.7 & 4.8 & 1.5 & 0.1 \\
\hline
\end{tabular}
soil 587 (Pram Point). These soils have not been disturbed by earthworks and are representative examples for each area. 

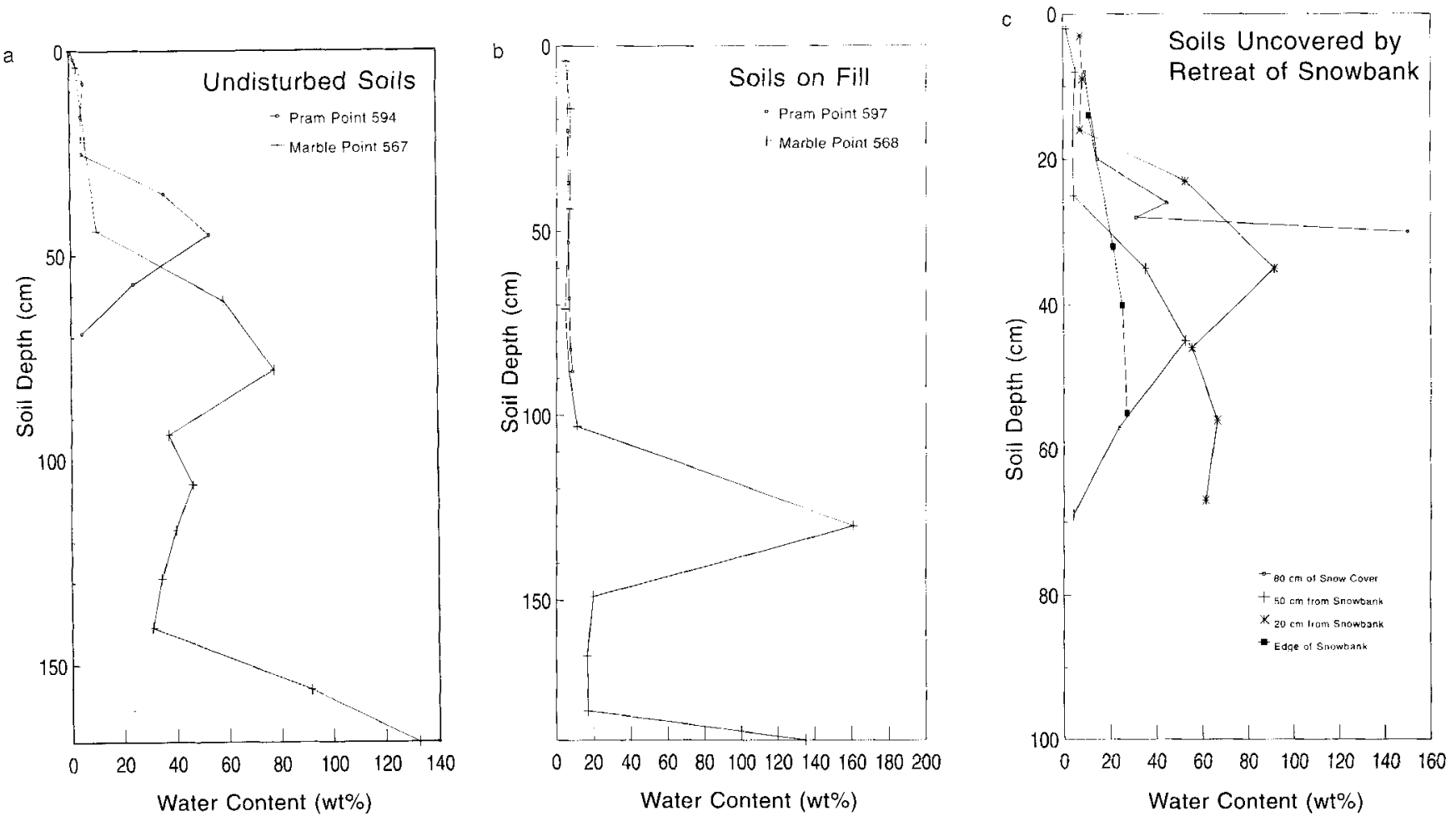

Fig. 1. Gravimetric moisture contents of some soils: a. Undisturbed soils from Marble Point and Pram Point. Note the low moisture contents above the permafrost level and the high and variable ice content below. b. Soils on fill from Marble Point and Pram Point, showing the low and relatively uniform moisture contents of these soils. c. Soils uncovered by retreat of a snowbank, Pram Point, showing the high ice content of the soil under the snowbank, the more uniform ice content of the soil on the edge, and the variable ice contents of the soils further from the snowbank edge.

of the fine earth fraction.

The fine earth fractions of the soils from Marble Point (Table II) are predominantly fine sand, with most material in the $0.2-0.1 \mathrm{~mm}$ fraction. The clay and silt contents are low, but increase in the lower part of the profile, especially in the permafrost. The coarser sand-sized particles are fragments of granite, schist and granodiorite derived from the local rocks, while the $0.2-0.1 \mathrm{~mm}$ size fraction consists largely of rounded quartz grains probably derived from disintegrated Beacon Supergroup sandstones and blown from inland areas. The clay fraction contains mica, chlorite and smectite, indicating the presence of some authigenic clay minerals. Disturbance does not change these characteristics greatly.

The Pram Point soils (Table II), are somewhat coarser in texture than those at Marble Point with the bulk of the fine earth fraction concentrated in the $2-0.5 \mathrm{~mm}$ size range. Clay contents are similar to those of the Marble Point soils, but do not show the same increase within the permafrost. Silt contents are somewhat higher, especially at the base of the active layer. The rock fragments and sand grains are basaltic, while the silt and clay fractions, although consisting largely of glassy materials, contain small amounts of quartz, mica and chlorite, consistent with a loessial origin.

In undisturbed sites, the fine earth content is significantly lower in the unconsolidated surface layer or desert pavement than in the loose material above the permafrost. This is typical of most Antarctic soils and is probably a result of winnowing of the surface particles by wind. The fine earth content of the active layer is higher than in the surface layer, but is less than in the icy permafrost beneath. This may be a consequence of the different sampling techniques used in frozen and unfrozen soil.

The fine earth content of the active layer in the disturbed runway (fill) soils is markedly greater than in the underlying frozensoil or the nearby undisturbed soils. These relatively high values are probably a reflection of the mechanics of runway construction and the use of fine soil materials. The proportions of fine earth in the disturbed scraped soils are similar to those of the fill materials although the contrast between active layer and permafrost horizons is less. One of the features of all horizons below the permafrost is the wide variability in particle size.

\section{Water soluble salts}

Water soluble salts (Table II) are concentrated in the surface horizon where they accumulate during surface evaporation. The soil above the icy permafrost contains only small amounts of salt, characteristic of soils in this climatic zone. Within the permafrost, salt concentrations are somewhat higher, around $0.5 \%$. The salts are largely sodium chloride and sodium 
Table III. Fine earth contents, moisture contents by weight and by volume, and the total excess ice in the upper part of the ice-cemented material for undisturbed soils from Marble Point.

\begin{tabular}{|c|c|c|c|c|c|}
\hline \multirow{2}{*}{$\begin{array}{l}\text { sample } \\
\text { no }\end{array}$} & \multirow{2}{*}{$\begin{array}{l}\text { depth } \\
\mathrm{cm}\end{array}$} & \multirow{2}{*}{$\begin{array}{c}<2 \mathrm{~mm} \\
\%\end{array}$} & \multicolumn{2}{|c|}{ moisture content } & \multirow{2}{*}{$\begin{array}{c}\text { total } \\
\text { excess ice }\end{array}$} \\
\hline & & & wt \% & vol \% & \\
\hline $566 \mathrm{~h}$ & $4-0$ & 25 & 0.5 & 0.9 & \\
\hline $566 \mathrm{i}$ & $0-27$ & 46 & 3.5 & 6.1 & \\
\hline $566 \mathrm{j}$ & $27-48$ & 44 & 4.3 & 7.5 & \\
\hline $566 \mathrm{k}$ & $48-65$ & 55 & 5.9 & 10.3 & \\
\hline \multicolumn{6}{|c|}{ ice-cement surface } \\
\hline $566 a$ & $65-80$ & 54 & 15.2 & 26.4 & \\
\hline $566 \mathrm{~b}$ & $80-95$ & 73 & 67.2 & 65.3 & \\
\hline $566 \mathrm{c}$ & $95-110$ & 80 & 20.9 & 36.4 & \\
\hline $566 \mathrm{~d}$ & $110-128$ & 65 & 22.9 & 39.0 & \\
\hline $566 \mathrm{e}$ & $128-148$ & 70 & 17.3 & 30.1 & \\
\hline $566 \mathrm{f}$ & $148-162$ & 68 & 15.0 & 26.1 & \\
\hline $566 \mathrm{~g}$ & $162-175$ & 39 & 10.4 & 18.1 & \\
\hline \multicolumn{5}{|c|}{ Excess ice content in ice-cemented material } & $351 \mathrm{~m}^{-3}$ \\
\hline $567 a$ & $2-0$ & 24 & 0.5 & 0.9 & \\
\hline $567 \mathrm{~b}$ & $0-8$ & 52 & 2.4 & 4.2 & \\
\hline $567 c$ & $8-35$ & 61 & 5.8 & 10.1 & \\
\hline $567 d$ & $35-52$ & 28 & 9.9 & 17.2 & \\
\hline \multicolumn{6}{|c|}{ ice-cement surface } \\
\hline $567 e$ & $52-70$ & 68 & 57.9 & 65.9 & \\
\hline $567 f$ & $70-86$ & 48 & 77.4 & 68.4 & \\
\hline $567 \mathrm{~g}$ & $86-102$ & 74 & 37.0 & 50.9 & \\
\hline $567 \mathrm{~h}$ & $102-110$ & 72 & 46.0 & 56.3 & \\
\hline $567 \mathrm{i}$ & $110-125$ & 48 & 39.9 & 52.8 & \\
\hline $567 \mathrm{j}$ & $125-133$ & 39 & 34.5 & 49.5 & \\
\hline $567 \mathrm{k}$ & $133-148$ & 29 & 30.9 & 46.4 & \\
\hline 5671 & $148-164$ & 17 & 91.5 & 71.9 & \\
\hline $567 \mathrm{~m}$ & $164-173$ & 78 & 132.6 & 78.8 & \\
\hline \multicolumn{5}{|c|}{ Excess ice content in ice-cemented material } & $1811 \mathrm{~m}^{-3}$ \\
\hline $587 a$ & $0-5$ & 47 & 1.8 & 3.1 & \\
\hline $587 \mathrm{~b}$ & $5-10$ & 62 & 4.4 & 7.7 & \\
\hline $587 \mathrm{c}$ & $10-15$ & 37 & 4.6 & 8.0 & \\
\hline $587 \mathrm{~d}$ & $15-20$ & 41 & 4.5 & 7.8 & \\
\hline $587 \mathrm{e}$ & $20-28$ & 31 & 4.2 & 7.3 & \\
\hline \multicolumn{6}{|c|}{ ice-cement surface } \\
\hline $587 f$ & $28-34$ & 58 & 13.2 & 23.0 & \\
\hline $587 \mathrm{~g}$ & $34-45$ & 31 & 19.4 & 33.7 & \\
\hline $587 \mathrm{~h}$ & $45-57$ & 62 & 33.4 & 48.3 & \\
\hline $587 \mathrm{i}$ & $57-63$ & 65 & 59.7 & 62.6 & \\
\hline \multicolumn{5}{|c|}{ Excess ice content in ice-cemented material } & $801 \mathrm{~m}^{-3}$ \\
\hline $588 \mathrm{a}$ & $0-5$ & 50 & 10.2 & 17.7 & \\
\hline $588 \mathrm{~b}$ & $5-10$ & 39 & 6.1 & 10.6 & \\
\hline $588 \mathrm{c}$ & $10-15$ & 43 & 8.3 & 14.4 & \\
\hline $588 \mathrm{~d}$ & $15-20$ & 37 & 7.4 & 12.9 & \\
\hline $588 \mathrm{e}$ & $20-25$ & 35 & 6.6 & 11.5 & \\
\hline \multicolumn{6}{|c|}{ ice-cement surface } \\
\hline $588 \mathrm{f}$ & $25-31$ & 40 & 31.4 & 46.8 & \\
\hline $588 \mathrm{~g}$ & $31-45$ & 36 & 28.8 & 44.7 & \\
\hline $588 \mathrm{~h}$ & $45-47$ & 60 & 36.7 & 50.7 & \\
\hline \multicolumn{5}{|c|}{ Excess ice content in ice-cemented material } & $58 \mathrm{~lm}^{-3}$ \\
\hline
\end{tabular}

sulphate, although other ions are also present.

Cutsurfaces, especially at Pram Point, often show pronounced efflorescences and these are considered to originate from salts contained within the permafrost, which are released upon thawing.

\section{Water contents in the active zone}

The moisture contents of undisturbed Marble Point soils are very low in the upper horizons, and increase slightly towards the permafrost surface. Within the permafrost they are much higher and very variable (Fig. 1a). The proportion of the pore space occupied by water increases towards the permafrost surface, but is nowhere more than $50 \%$ saturated. The very low moisture contents of the surface soils may, in part, account for the meagre occurrence of plant life in Antarctica. Moisture contents within the permafrost are not always sufficient to fully saturate all of the soil material. In one of the undisturbed sites at Marble Point (566), excess ice is present only in one horizon, while in the other (567), the whole of the upper metre of the icy permafrost contains excess ice (Table III).

The moisture contents of the undisturbed Pram Point soils (Table III) have a similar distribution pattern to those at Marble Point, with low values above the surface of the permafrost table, followed by a rise immediately below it. Within the permafrost, soils are saturated with ice or contain excess ice.

The moisture characteristics of the soil on fill materials (568) are somewhat different (Table IV and Fig. 1b). The moisture content of the active layer is similar to that of the undisturbed soils but, immediately below the permafrost surface, it is low, rather than increasing rapidly as in the undisturbed soils. The lower portion of the profile however has moisture contents similar to those of the undisturbed soils, with indications of the presence of ice lenses in parts of the profile.

Another soil (site 583), on a low artificial ridge about $1 \mathrm{~m}$ high and $2 \mathrm{~m}$ wide, also had low moisture contents in the active layer and only slightly higher values in the frozen disturbed soil below.

These results suggest that the re-establishment of ice-cement may be a slow process, as ice has not accumulated close to the new permafrostsurface despite the apparently favourable seasonal conditions of extensive snow cover and thaw. Presumably, there is insufficient moisture available to saturate the soil, and movement of air through pore spaces permits losses of water by evaporation.

The moisture contents of soils on compacted fill material forming the base for a pipeline at Pram Point, sampled six weeks after construction, increase slightly with depth, being somewhat higher than in undisturbed unfrozen soils. While the moisture content of the soil materials when put in place is not known, it was probably the same throughout the fill. The values shown in Table IV suggest that a moisture gradient within the soil may already have become established.

In soils of scraped surfaces at Marble Point (Table V), moisture contents in the active layer are comparable to those immediately below the permafrost surface. During the runway construction, it is probable that these areas were scraped free of loose surface soil down to the permafrost surface, and ablation or melting of the ice contained in the exposed ice-cemented material of the newly formed active layer must have resulted in a significant loss of soil water. Below this, however, the ice 
Table IV. Fine earth contents, moisture contents by weight and by volume, and the total excess ice in the upper part of the ice-cemented material for soils on fill material from Marble Point, and on compacted fill, six weeks after construction, Pram Point.

\begin{tabular}{|c|c|c|c|c|c|}
\hline \multirow{2}{*}{$\begin{array}{l}\text { sample } \\
\text { no }\end{array}$} & \multirow{2}{*}{$\begin{array}{l}\text { depth } \\
\mathrm{cm}\end{array}$} & \multirow{2}{*}{$\begin{array}{c}<2 \mathrm{~mm} \\
\%\end{array}$} & \multicolumn{2}{|c|}{ moisture content } & \multirow{2}{*}{$\begin{array}{r}\text { total } \\
\text { excess ice }\end{array}$} \\
\hline & & & wt \% & vol \% & \\
\hline $568 \mathrm{a}$ & $0-8$ & 72 & 4.9 & 8.5 & \\
\hline $568 b$ & $8-25$ & 99 & 7.5 & 13.1 & \\
\hline $568 \mathrm{c}$ & $25-62$ & 61 & 7.3 & 12.7 & \\
\hline \multicolumn{6}{|c|}{ ice-cement surface } \\
\hline $568 \mathrm{~d}$ & $62-80$ & 46 & 4.7 & 8.2 & \\
\hline $568 \mathrm{e}$ & $80-96$ & 52 & 6.7 & 11.7 & \\
\hline $568 \mathrm{f}$ & $96-119$ & 52 & 10.9 & 19.0 & \\
\hline $568 \mathrm{~g}$ & 119-141 & 52 & 161.0 & 81.9 & \\
\hline $568 \mathrm{~h}$ & $141-156$ & 44 & 19.7 & 34.3 & \\
\hline $568 \mathrm{i}$ & $156-174$ & 39 & 16.5 & 28.7 & \\
\hline $568 \mathrm{j}$ & $174-185$ & 43 & 17.0 & 29.6 & \\
\hline $568 \mathrm{k}$ & $185-190$ & 49 & 135.0 & 79.1 & \\
\hline \multicolumn{5}{|c|}{ Excess ice content in ice-cemented material } & $861 \mathrm{~m}^{-3}$ \\
\hline $570 \mathrm{a}$ & $0-10$ & 81 & 2.1 & 3.7 & \\
\hline $570 \mathrm{~b}$ & $10-30$ & 59 & 3.6 & 6.3 & \\
\hline $570 \mathrm{c}$ & $30-67$ & 42 & 3.5 & 6.1 & \\
\hline \multicolumn{6}{|c|}{ ice-cement surface } \\
\hline $570 \mathrm{~d}$ & $67-75$ & 32 & 56.0 & 61.1 & \\
\hline $570 \mathrm{e}$ & $75-81$ & 34 & 5.8 & 10.1 & \\
\hline $570 \mathrm{f}$ & $81-85$ & 23 & 4.2 & 7.3 & \\
\hline \multicolumn{5}{|c|}{ Excess ice content in ice-cemented material } & $94 \mathrm{l} \mathrm{m}^{-3}$ \\
\hline $583 a$ & $0-10$ & 63 & 2.5 & 4.4 & \\
\hline $583 b$ & $25-35$ & 49 & 3.5 & 6.1 & \\
\hline $583 \mathrm{c}$ & $55-65$ & 50 & 4.4 & 7.7 & \\
\hline \multicolumn{6}{|c|}{ ice-cement surface } \\
\hline $583 \mathrm{~d}$ & $85-90$ & 51 & 13.1 & 22.8 & \\
\hline $583 \mathrm{e}$ & $90-94$ & 49 & 10.6 & 18.4 & \\
\hline $583 \mathrm{f}$ & $94-100$ & 61 & 13.0 & 22.6 & \\
\hline \multicolumn{5}{|c|}{ Excess ice content in ice-cemented material } & none \\
\hline $597 a$ & $0-15$ & - & 6.0 & 11.0 & \\
\hline $597 \mathrm{~b}$ & $15-30$ & - & 6.1 & 11.1 & \\
\hline \multicolumn{6}{|c|}{ ice-cement surface } \\
\hline $597 \mathrm{c}$ & $30-45$ & - & 6.3 & 11.0 & \\
\hline $597 \mathrm{~d}$ & $45-60$ & - & 6.4 & 11.1 & \\
\hline $597 \mathrm{e}$ & $60-75$ & - & 6.9 & 12.0 & \\
\hline $597 \mathrm{f}$ & $75-90$ & - & 7.5 & 13.1 & \\
\hline $597 \mathrm{~g}$ & $80-95$ & - & 8.4 & 14.0 & \\
\hline \multicolumn{5}{|c|}{ Excess ice content in ice-cemented material } & none \\
\hline $598 \mathrm{a}$ & $0-15$ & - & 6.2 & 10.8 & \\
\hline $598 \mathrm{~b}$ & $15-30$ & - & 6.5 & 11.3 & \\
\hline \multicolumn{6}{|c|}{ ice-cement surface } \\
\hline $598 \mathrm{c}$ & $30-45$ & - & 6.3 & 11.0 & \\
\hline $598 \mathrm{~d}$ & $45-60$ & - & 6.9 & 12.0 & \\
\hline $598 \mathrm{e}$ & $60-75$ & - & 7.1 & 12.4 & \\
\hline $598 \mathrm{f}$ & $75-90$ & - & 6.3 & 11.0 & \\
\hline $598 \mathrm{~g}$ & $90-95$ & - & 6.3 & 11.0 & \\
\hline \multicolumn{5}{|c|}{ Excess ice content in ice-cemented material } & none \\
\hline
\end{tabular}

content of the soil has remained much as it was before disturbance. The higher water content values in the active layer appeared to be due to seepage of water into the scraped area, which now forms a hollow.

At Pram Point, snowbanks are in general retreat as a result of decreased albedo caused by dust deposition. Adjacent to and
Table V. Fine earth contents, moisture contents by weight and by volume for soils from which the surface has been scraped off at Marble Point.

\begin{tabular}{|c|c|c|c|c|c|}
\hline \multirow{2}{*}{$\begin{array}{l}\text { sample } \\
\text { no }\end{array}$} & \multirow{2}{*}{$\begin{array}{l}\text { depth } \\
\mathrm{cm}\end{array}$} & \multirow{2}{*}{$\begin{array}{c}<2 \mathrm{~mm} \\
\%\end{array}$} & \multicolumn{2}{|c|}{ moisture content } & \multirow{2}{*}{$\begin{array}{r}\text { total } \\
\text { excess ice }\end{array}$} \\
\hline & & & wt $\%$ & vol \% & \\
\hline $569 a$ & $0-15$ & 70 & 7.3 & 12.7 & \\
\hline $569 \mathrm{~b}$ & $15-30$ & 92 & 8.8 & 15.3 & \\
\hline $569 c$ & $30-60$ & 59 & 6.7 & 11.7 & \\
\hline \multicolumn{6}{|c|}{ ice-cement surface } \\
\hline $569 d$ & $66-81$ & 88 & 8.9 & 15.5 & \\
\hline $569 \mathrm{e}$ & $81-93$ & 80 & 10.2 & 17.7 & \\
\hline $569 f$ & $93-103$ & 8 & 9.7 & 16.9 & \\
\hline $569 \mathrm{~g}$ & $103-111$ & 44 & 8.6 & 15.0 & \\
\hline
\end{tabular}

Excess ice content in ice-cemented material

none

\begin{tabular}{lcccc}
$571 \mathrm{a}$ & $0-29$ & 59 & 6.5 & 11.3 \\
$571 \mathrm{~b}$ & $29-35$ & 58 & 16.6 & 28.4 \\
$571 \mathrm{c}$ & $35-38$ & 33 & 6.7 & 11.7 \\
$571 \mathrm{~d}$ & $38-39$ & \multicolumn{3}{c}{ thin horizon not analysed } \\
$571 \mathrm{e}$ & $39-46$ & 45 & 11.2 & 19.5 \\
$571 \mathrm{f}$ & $46-58$ & 79 & 17.0 & 29.6 \\
ice-cement surface & & & \\
$571 \mathrm{~g}$ & $58-73$ & 32 & 6.9 & 12.2 \\
$571 \mathrm{~h}$ & $73-79$ & 39 & 9.9 & 17.2 \\
$571 \mathrm{i}$ & $79-96$ & 48 & 15.1 & 26.3 \\
$571 \mathrm{j}$ & $96-105$ & 47 & 10.9 & 19.6 \\
$571 \mathrm{k}$ & $105-115$ & 49 & 12.6 & 21.9 \\
$5711 \mathrm{l}$ & $115-132$ & 74 & 16.6 & 28.4 \\
$571 \mathrm{~m}$ & $132-152$ & 54 & 20.0 & 34.8
\end{tabular}

Excess ice content in ice-cemented material none

beneath a retreating snowbank (Table $\mathrm{V}$ and Fig. 1c), the soil was found to be hard frozen to the surface while the depth to permafrost increased with increasing distance from the snowbank. The soils near or beneath snow banks have high water contents at or near the surface and the data for these sites suggests that when permanent snow cover retreats, water is soon lost from the soil surface as the permafrost table moves downwards.

\section{Patterned ground and permafrost variability}

In the investigations at Marble Point and Pram Point permafrost observations were made at 34 sites and the data presented in Tables III-V and in Fig. 1 are representative of the results for all sites. For the undisturbed sites, the sample locations were close to the centre of a patterned ground unit. The ice contents of the upper part of the permafrost ranged from $22-79 \%$ by volume at Marble Point and from 27-62\% at Pram Point. Generally the values represent filling of much of the pore space with ice, while excess ice, indicating the presence of ice lenses, is present in many parts of the profiles. There is no apparent spatial pattern in the distribution of excess ice in the soils. It is expected that even greater variability would be encountered between the centre and edge of a polygon where ice wedges commonly occur.

At Marble Point, in late January 1990, the average depth to the surface of the ice cemented soil was $61 \mathrm{~cm}$ while in December 1991 it was $41 \mathrm{~cm}$. The deeper values in January probably represent the maximum depth of the active layer. At Pram Point the average depth was $30 \mathrm{~cm}$ during late January and early 
Table VI. Fine earth contents, moisture contents by weight and by volume, and the total excess ice in the upper part of the ice-cemented material, for soils exposed by retreat of a permafrost snowbank, Pram Point.

\begin{tabular}{|c|c|c|c|c|c|}
\hline \multirow{2}{*}{$\begin{array}{l}\text { sample } \\
\text { no }\end{array}$} & \multirow{2}{*}{$\begin{array}{l}\text { depth } \\
\mathrm{cm}\end{array}$} & \multirow{2}{*}{$\begin{array}{c}<2 \mathrm{~mm} \\
\%\end{array}$} & \multicolumn{2}{|c|}{ moisture content } & \multirow{2}{*}{$\begin{array}{r}\text { total } \\
\text { excess ice }\end{array}$} \\
\hline & & & wt $\%$ & vol \% & \\
\hline $594 a$ & $0-4$ & 52 & 1.4 & 2.4 & \\
\hline $594 b$ & $4-12$ & 44 & 5.3 & 9.6 & \\
\hline $594 c$ & $12-20$ & 37 & 4.2 & 7.3 & \\
\hline $594 d$ & $20-30$ & 41 & 4.4 & 7.7 & \\
\hline \multicolumn{6}{|c|}{ ice-cement surface } \\
\hline $594 \mathrm{e}$ & $30-40$ & 58 & 35.4 & 49.8 & \\
\hline $594 \mathrm{f}$ & $40-50$ & 47 & 52.8 & 59.7 & \\
\hline $594 \mathrm{~g}$ & $50-63$ & 53 & 23.8 & 40.0 & \\
\hline $594 \mathrm{~h}$ & $63-75$ & 64 & 4.2 & 7.3 & \\
\hline \multicolumn{5}{|c|}{ Excess ice content in ice-cemented material } & $651 \mathrm{~m}^{-3}$ \\
\hline $595 a$ & $0-5$ & 53 & 7.4 & 12.9 & \\
\hline $595 b$ & $5-12$ & 70 & 8.2 & 14.3 & \\
\hline $595 c$ & $12-20$ & 59 & 7.1 & 12.4 & \\
\hline \multicolumn{6}{|c|}{ ice-cement surface } \\
\hline 595d & $20-27$ & 54 & 52.8 & 59.7 & \\
\hline $595 \mathrm{e}$ & $27-41$ & 61 & 91.6 & 72.0 & \\
\hline $595 \mathrm{f}$ & $41-50$ & 70 & 55.5 & 60.9 & \\
\hline $595 \mathrm{~g}$ & $50-61$ & 74 & 66.6 & 65.1 & \\
\hline $595 \mathrm{~h}$ & $61-75$ & 73 & 61.4 & 63.2 & \\
\hline \multicolumn{5}{|c|}{ Excess ice content in ice-cemented material } & $2581 \mathrm{~m}^{-3}$ \\
\hline $596 a$ & $0-27$ & 59 & 11.0 & 19.1 & \\
\hline $596 \mathrm{~b}$ & $27-37$ & 50 & 21.4 & 37.2 & \\
\hline $596 \mathrm{c}$ & $37-44$ & 59 & 25.4 & 41.6 & \\
\hline 596d & $44-66$ & 70 & 27.3 & 43.3 & \\
\hline \multicolumn{5}{|c|}{ Excess ice content in ice-cemented material } & $101 \mathrm{l} \mathrm{m}^{-3}$ \\
\hline $589 a$ & $0-15$ & 66 & 9.1 & 15.8 & \\
\hline $589 \mathrm{~b}$ & $15-25$ & 55 & 14.8 & 25.8 & \\
\hline $589 c$ & $25-27$ & nd & 44.8 & 55.7 & \\
\hline $589 d$ & $27-29$ & 57 & 31.5 & 46.9 & \\
\hline $589 \mathrm{e}$ & $29-31$ & 86 & 150.1 & 80.8 & \\
\hline \multicolumn{5}{|c|}{ Excess ice content in ice-cemented material } & $41 \mathrm{I} \mathrm{m}^{-3}$ \\
\hline \multicolumn{5}{|c|}{ Total moisture content of frozen soil } & $30601 \mathrm{~m}^{-3}$ \\
\hline
\end{tabular}

February 1990 and late December 1991. The thicker active layer at Marble Point may be a result of differences in local climate and aspect.

\section{Discussion}

\section{Ice contents}

Although there do not appear to have been any previous estimates of the ice content of Antarctic permafrost the values are similar to those found in the Arctic regions. Pollard \& French(1980), for example, calculated the volume of groundice contained in Richards Island, in the Canadian Arctic. They estimated ice contents from published drill log information and estimates of the soil physical properties, and concluded that ice made up $47.5 \%$ of the volume of the perennially frozen ground, but that excess ice, i.e. that over and above that required to fill the available pore space, was only $14 \%$. They estimated that the volume of ice contained in ice wedges, pingos and other similar small ice bodies was small compared with the total volume. Therefore melting of the permafrost layer in the area they investigated would cause a lowering of the surface by $14 \%$.

Where permanent snow accumulations in nivation cirques and snow fields are retreating because of dust effects on albedo, water is gradually lost from the soil and the permafrost retreats from the surface. Where there is extensive ground ice accumulation, rapid loss of snow cover sometimes results in ground shrinkage and minor soil slumping.

Soil material that is removed from above the permafrost and placed elsewhere does not develop a new ice-rich permafrost horizon quickly, even though sufficient moisture may be present. This suggests that the development of soil moisture gradients in Antarctic soils may be strongly influenced by surface conditions, including low humidity and high evaporation potential. The extremely porous nature of the soil allows any liquid water available to drain away before it freezes, preventing the buildup of excess ice within the active layer.

\section{Permafrost changes after land disturbance}

Disturbance of the land surface by removal of loose soil above the ice-cement surface results in retreat of the permafrost table and consequent melting of the ice contained in the upper part of the permafrost (which may be greater than $80 \%$ of the soil volume), and loss of the water by ablation or runoff. This water loss may occur within a few weeks of the disturbance, with the soils sometimes becoming temporarily saturated as they thaw. Where excess ice is present as wedges, ice melting commonly causes collapse of surrounding soil into the resulting space, forming polygonal patterns on the surface. In some areas that have been scraped, the loss of water from the ice-cement has been accompanied by extensive precipitation of soluble salts on the soil surface, indicating that much of the water loss is by evaporation from the ice-cement, which has been shown to have a higher soluble salt content than the overlying material.

Up to 2501 of water would be released by the melting of a cubic metre of permafrost. If the permafrost surface level were reduced by $50 \mathrm{~cm}$ by the removal of the active layer above and thawing allowed to proceed until a new equilibrium were established, up to $1250 \mathrm{~m}^{3}$ of water would be released per hectare. This excludes the volume ofice contained in ice wedges and other ice segregations not studied in this investigation. Because the variability in excess ice volume tends to be uneven, thawing leads to a hummocky ground surface. The surface would be lowered a further $5-15 \mathrm{~cm}$ overall.

\section{Rehabilitation of disturbed surfaces}

Most land surfaces in Antarctica are dominated by patterned ground, the surface expression of a network of ice wedges in the underlying permafrost. The extensive areas of scraped and redeposited soils at Marble Point, unmodified since 1959, provide some indication of the processes that form the surface features. On scraped areas, for example, some shallow patterned 
ground cracks had formed, but these could be seen to be part of a former polygon network and the troughs on the scraped surfaces only mark the position of previous ice wedges which melted out after the land was scraped. Occasionally, polygonal cracks were observed to extend from a scraped surface to redistributed material nearby but in general, redeposited soil material showed little sign of new patterned ground formation, presumably because the ice content in the upper newly formed permafrost is too low. Some minor surface reworking on mounds of redeposited soil occurred as shallow solifluction flows.

The extensive occurrences of surface salt efflorescences on land surfaces several years after disturbance as a result of release of salts held within the permafrost is a further indication of disturbance. Such surfaces may from a distance appear snowcovered. The re-establishment of a chemical equilibrium within the soil and the dispersal of the excess salt from the surface may take many decades.

\section{Conclusions}

The active layer of the soils are characterized by very low water contents at the soil surface and the water content rises steadily, although still low, towards the permafrost table. In the permafrost, the excess ice content of the upper metre of the undisturbed soils at Marble Point and Pram Point is in the order of $10-25 \%$ by volume. The soils are in most cases fully saturated with ice and contain irregular segregations of excess ice over and above that required for saturation. This contrasts with the water content of the permafrost in soils from drier inland regions where it is known that ice cementing in the permafrost is absent.

When disturbed by removal of the surface layer of frozen material, the permafrost thaws to a depth similar to that existing before disturbance and loses the excess moisture by evaporation, sublimation or runoff. If $50 \mathrm{~cm}$ of permafrost (the maximum depth of penetration of the freezing isotherm in these regions) were to melt this would then result in a lowering of ground surface by $5-12 \mathrm{~cm}$ and the release of up to $1250 \mathrm{~m}^{3}$ of water per hectare. Salts contained within the permafrost are left as efflorescences on the new soil surfaces. On filled sites, the permafrost table rises but shows no sign of regaining its original ice content. Even after thirty years exposure only small amounts of ice have accumulated.

\section{Acknowledgements}

The authors acknowledge the Foundation for Research, Science and Technology and the New Zealand Lottery Grants Board for financial assistance, and the NewZealand Antarctic Programme for logistic support. We are grateful to Prof. W. Karlén and Dr C. Harris for reviewing the manuscript.

\section{References}

CAMPBELL, I.B., \& ClaRIDGE, G.G.C. 1975. Morphology and age relationships of Antarctic soils. In SugGaTe R.P. \& CREsSWELL, M.M., eds. Quaternary Studies. Royal Society of New Zealand Bulletin, No. 13, 83-88.

CAMPBeIL, I.B., \& ClaRIRGE, G.G.C. 1987. Antarctica: soils, weathering processes and environment. Amsterdam: Elsevier Science Publishers, 368 pp.

MEHRA, O.P. \& JACKSON, M.L. 1960. Iron oxide removal from soils and clays by a dithionite-citrate system buffered with sodium bicarbonate. Clays and Clay Minerals, 7, 317-337.

Metson, A.J. 1956. Methods of chemical analysis for soil survey samples. New Zealand Soil Bureau Bulletin, 12, 12.

POLARD, W.H. \& FRENCH, H.M. 1980. A first approximation of the volume of ground ice, Richards Island, Pleistocene Mackenzie delta, Northwest Territories, Canada. Canadian Geotechnical Journal, 17, 509-516. 